\title{
A Modified, Highly Sensitive Enzyme-linked Immunosorbent Assay (ELISA) for Rhizobium meliloti Strain Identification
}

\author{
By ANNA M. MARTENSSON, * JAN-GUNNAR GUSTAFSSON† \\ AND HANS D. LJUNGGREN \\ Department of Microbiology, Swedish University of Agricultural Sciences, S-750 07 Uppsala, \\ Sweden
}

(Received 27 June 1983; revised 26 July 1983)

\begin{abstract}
An evaluation of the ELISA technique was made in order to obtain a very specific and sensitive method for strain identification of Rhizobium meliloti. Antisera against an $R$. meliloti strain were produced by using as antigen either whole cells or purified lipopolysaccharides from the cell wall. The use of whole cells as antigen gave rise to antibodies which were more sensitive and strain specific than those produced from purified lipopolysaccharides. A further evaluation of the ELISA method was the use of a new type of conjugate consisting of a purified antibody linked to $\beta$-galactosidase by using as coupling reagent a hetero-bifunctional reagent, $N$ succinimidyl-3-(2-pyridyldithio)propionate (SPDP), which contains two reactive groups directed towards different functional groups. Substrate for this type of conjugate consisted of $o$-nitrophenyl- $\beta$-D-galactopyranoside. This improved technique makes it possible to detect bacteria in samples containing $1 \times 10^{3}$ cells $\mathrm{ml}^{-1}$ whilst retaining strain specificity. Furthermore, preparations of nodules formed by different $R$. meliloti strains containing $1 \times 10^{5}$ cells $\mathrm{ml}^{-1}$ could be analysed whilst retaining strain specificity. The technique presented thus offers advantages in higher sensitivity and reliability than conventional ELISA techniques.
\end{abstract}

\section{INTRODUCTION}

The production of effective inoculants for agricultural use presumes a sensitive method for detection of bacteria used as inoculant. Otherwise, it will be impossible to answer such questions as: what is the competitive ability of the introduced strain against indigenous rhizobia and other soil organisms; how often is it necessary to re-inoculate; and is it possible by soil management to encourage or discourage the development of an effective symbiosis?

Until recently the agglutination and immunodiffusion tests (Vincent, 1970) have been the ones most commonly used for Rhizobium strain identification. However, these methods require isolation and subculture if, for instance, nodule-forming bacteria are to be tested. The specificity is low and the readout of the tests is not fully objective. Other marker techniques for recognizing rhizobia are the use of genetic markers by antibiotic resistance (Schwinghamer \& Dudman, 1971), and auxotrophy (Johnston \& Beringer, 1975). The uncertainty associated with the genetic stability makes these techniques doubtful.

With the introduction of enzyme-labelled antibodies (Nakane \& Pierce, 1966; Wicker \& Avrameas, 1969) for the detection of virus antigens in tissue culture, a possibility for detecting different strains of micro-organisms became available. The quantitative use of enzyme-labelled antibodies was reported by Engvall \& Perlmann (1971); Engvall \& Perlmann (1972) claimed

† Present address: Pharmacia Fine Chemicals, Box 175, S-750 07 Uppsala, Sweden.

Abbreviations: KDO, 2-ketodeoxyoctonate; LPS, lipopolysaccharide; SPDP, $N$-succinimidyl-3-(2-pyridyldithio)propionate. 
that the enzyme-linked immunosorbent assays had sensitivities comparable to radioimmunoassays and offered several advantages over them, for instance the elimination of health risks due to radiation, ability to store the conjugates for long periods of time and less expensive equipment for analysis. The ELISA method has been extended from the medical research field to applications in the biological sciences. Plant viruses were detected by Clark \& Adams (1977) using a 'double antibody sandwich' as presented by Voller et al. (1976). The use of ELISA for identification of Rhizobium was reported by Kishinevsky \& Bar-Joseph (1978), investigating nodules of Arachis hypogaea. Berger et al. (1979) avoided the difficulties in obtaining specific antibodies due to the nature of the cell wall of Rhizobium by using sheep anti-rabbit globulin for conjugation with alkaline phosphatase. A further modification was the use of fluorescent substrate to improve the sensitivity of the test (Morley \& Jones, 1980). In the present study, a further improvement of the sensitivity of the ELISA test is described. Modifications have been made by using $\beta$-galactosidase for conjugation, the enzyme being coupled to the purified gamma-globulin by a hetero-bifunctional reagent.

\section{METHODS}

Preparation of antigen. Rhizobium meliloti strain 29 (Leguminous Plant Laboratory, Swedish University of Agricultural Sciences) was grown on a defined medium (Bishop et al., 1976) in a 4-1 fermenter containing 3.51 substrate at $28^{\circ} \mathrm{C}$, supplied with 0.31 air (1 substrate) $)^{-1} \mathrm{~min}^{-1}$; the $\mathrm{pH}$ was kept at 7.0 by automatic titration with $\mathrm{KOH}$. After $30 \mathrm{~h}$ growth the cells were harvested. One litre of the cell suspension was cooled to $2^{\circ} \mathrm{C}$ and centrifuged at $5000 \mathrm{~g}$ for $15 \mathrm{~min}$ at $2{ }^{\circ} \mathrm{C}$, washed twice with $2 \times 200 \mathrm{ml} 0.02 \mathrm{M}$-sodium phosphate buffer $/ 0.02 \mathrm{M}$ $\mathrm{NaCl}, \mathrm{pH} 7.0$ and stored frozen at $-70^{\circ} \mathrm{C}$ for later use for immunization with whole cells.

The rest of the cell mass was used for phenol/water extraction of the cell wall lipopolysaccharide (LPS) (Westphal \& Jann, 1965), with the following modifications involving the removal of nucleic acids in the crude LPS extract. After dialysis, the LPS-containing material $(185 \mathrm{ml})$ was passed through a $10 \mathrm{ml}$ bed of Dowex AG $1 \times 1$ in $1 \mathrm{M}$-acetic acid (Bio-Rad) and evaporated at room temperature to $130 \mathrm{ml}$. The concentrated LPS solution was made $10 \mathrm{mM}$ with respect to $\mathrm{MgSO}_{4}$ and $50 \mathrm{~mm}$ with respect to Tris $/ \mathrm{HCl}$, and adjusted to $\mathrm{pH} 7 \cdot 1$. RNAase A ( $2 \mathrm{mg}, 60 \mathrm{kUnits} \mathrm{mg}^{-1}$, EC 3.1.27.5, Sigma) and $2 \mathrm{mg}$ DNAase I (2 mg, $2150 \mathrm{kUnits} \mathrm{mg}^{-1}, \mathrm{EC} 3.1 .22 .1$, Sigma) was added and the solution was stirred overnight at $5{ }^{\circ} \mathrm{C}$ and later lyophilized. The lyophilized LPScontaining preparation was dissolved in $25 \mathrm{ml}$ of a buffer containing $20 \mathrm{~mm}$-imidazole- $\mathrm{HCl} / 100 \mathrm{mM}-\mathrm{NaCl}$, pH 7.1, and chromatographed on a DEAE-Sepharose CL-6B (Pharmacia) chromatography column $(2.5 \times 40 \mathrm{~cm})$, all fractions being analysed for 2-ketodeoxyoctonate (KDO) by the thiobarbituric acid method by Weissbach \& Hurwitz (1958). KDO-positive fractions were lyophilized and dissolved in $12.5 \mathrm{ml}$ of a buffer containing $10 \mathrm{mM}$ EDTA and $300 \mathrm{~mm}$-triethylamine, $\mathrm{pH} 7 \cdot 1$, and chromatographed on a Sepharose 4B chromatography column (2.5 $\times 40 \mathrm{~cm}$, Pharmacia); the eluted KDO-positive fractions containing LPS were lyophilized.

Production of antisera. A $1 \mathrm{ml}$ portion of a bacterial suspension $\left(10^{9}\right.$ cells $\left.\mathrm{ml}^{-1}\right)$ and $1 \mathrm{ml}$ of an LPS saline $(0.85 \%)$ solution containing $50 \mu \mathrm{g}$ of purified LPS $\mathrm{ml}^{-1}$ was mixed with Freund's complete adjuvant $(1: 1)$ and injected through the marginal ear vein of rabbits. After two and four weeks the injections were repeated; a month later a booster dose was given consisting of $1 \mathrm{ml}$ bacteria or LPS concentrations as earlier described mixed with Freund's incomplete adjuvant $(1: 1)$. One week after the booster was given the rabbits were bled, and the blood was allowed to clot for $4 \mathrm{~h}$ at room temperature. The serum was collected and $3 \mathrm{ml}$ fractions were stored frozen $\left(-70^{\circ} \mathrm{C}\right)$ before use.

Antibody purification. To samples of $2 \times 3 \mathrm{ml}$ of the respective antisera $1 \mathrm{ml} 0.02 \mathrm{M}$-sodium phosphate buffer, pH 7.4, was added. Drop by drop, $5 \mathrm{ml}$ saturated ammonium sulphate (pH 6.6 by titration with ammonium hydroxide) was added with vigorous stirring, the precipitate being stirred for $15 \mathrm{~min}$ and then allowed to settle for $7 \mathrm{~h}$ at room temperature. The precipitate was centrifuged $(70000 \mathrm{~g})$ for $2 \mathrm{~h}$ at $5^{\circ} \mathrm{C}$. T he supernatant was pipetted off and the gamma-globulin was dissolved in $5 \mathrm{ml} 0.02 \mathrm{M}$-sodium phosphate buffer, pH 7.2. Then $20 \mathrm{ml} 0.1 \mathrm{M}-$ $\mathrm{NaCl}, \mathrm{pH} 7 \cdot 1$, was added and the solution was concentrated to $5 \mathrm{ml}$ by ultrafiltration, using an Amicon ultrafilter cell equipped with a PM 30 membrane. Then $20 \mathrm{ml} 0 \cdot 1 \mathrm{M}$-sodium phosphate $/ 0 \cdot 1 \mathrm{M}-\mathrm{NaCl}, \mathrm{pH} 7 \cdot 1$, was added to the filter cell and the antibody solution was concentrated to $6 \mathrm{ml}$ and pipetted off and set apart. A further $2 \mathrm{ml}$ of $0 \cdot 1 \mathrm{M}-$ sodium phosphate $/ 0 \cdot 1 \mathrm{M}-\mathrm{NaCl}, \mathrm{pH} 7 \cdot 1$, was added to the ultrafilter cell and allowed to stand for $5 \mathrm{~min}$; it was then added to the gamma-globulin concentrate and diluted by adding $24 \mathrm{ml}$ distilled water. Separation of active and inactive gamma-globulins in the solutions was made by column chromatography, using a DEAE-Sephadex A-50 column (Pharmacia, $1.8 \times 10 \mathrm{~cm}$ ). The column was equilibrated with $0.02 \mathrm{M}$-sodium phosphate $/ 0.02 \mathrm{M}-\mathrm{NaCl}$, $\mathrm{pH} 6.5$; the gamma-globulin suspension was added to the column and a $\mathrm{NaCl}$ gradient was formed using $50 \mathrm{ml}$ $0.02 \mathrm{M}$-sodium phosphate $/ 0.02 \mathrm{M}-\mathrm{NaCl}, \mathrm{pH} 6.5$, as starting buffer and $50 \mathrm{ml} 0.02 \mathrm{M}$-sodium phosphate $/ 0.5 \mathrm{M}$ $\mathrm{NaCl}$, pH 6.5, as final buffer. Fractions containing active immunoglobulin $\mathrm{G}$ (IgG) were concentrated to $5 \mathrm{ml}$ by 
uitrafiltration as before. Then $25 \mathrm{ml} 0.1 \mathrm{M}$-sodium phosphate $/ 0 \cdot 1 \mathrm{M}-\mathrm{NaCl}, \mathrm{pH} 6.5$, was added to the filter cell, concentrated to $5 \mathrm{ml}$ and pipetted off. Again $2 \mathrm{ml}$ buffer was added to the filter cell and pipetted off after $5 \mathrm{~min}$; the total volume of active $\mathrm{IgG}$ was $7 \mathrm{ml}$, which was divided into $330 \mu \mathrm{l}$ samples and stored at $-70^{\circ} \mathrm{C}$.

Preparation of enzyme-conjugate. As a first step the concentration of the hetero-bifunctional reagent $N$ succinimidyl-3-(2-pyridyldithio)propionate (SPDP, Pharmacia) was estimated. SPDP (10 mg) was dissolved in $10 \mathrm{ml}$ ethanol and $20 \mu \mathrm{l}$ was added to $2.5 \mathrm{ml} 5 \mathrm{~mm}$-sodium phosphate, $\mathrm{pH} 7.0$. The $A_{260}$ was recorded immediately, after which $0.5 \mathrm{ml} 0.3 \mathrm{M}-\mathrm{Na}_{2} \mathrm{CO}_{3}, \mathrm{pH} 9.0$, was added and the $A_{260}$ read after $10 \mathrm{~min}$. The concentration of $N$ hydroxysuccinimide released from SPDP was calculated by dividing the change in absorbance by the molar extinction coefficient at $260 \mathrm{~nm}, 8.2 \times 10^{3} \mathrm{M}^{-1} \mathrm{~cm}^{-1}$ (Carlsson et al., 1978). Again $20 \mu \mathrm{l}$ of the stock solution of SPDP dissolved in ethanol was taken out and added to $3.0 \mathrm{ml} 50 \mathrm{~mm}$-sodium phosphate, $\mathrm{pH} 7 \cdot 0$. The $A_{343}$ was measured, $100 \mu \mathrm{l} 50 \mathrm{~mm}$-dithiothreitol was added and the $A_{343}$ was read again after $10 \mathrm{~min}$. The concentration of pyridine-2-thione released from SPDP was calculated by dividing the increase in absorbance by the molar extinction coefficient at $343 \mathrm{~nm}, 8.08 \times 10^{3} \mathrm{M}^{-1} \mathrm{~cm}^{-1}$ (Stuchbury et al., 1975). The molar concentration of $N$ hydroxysuccinimide was regarded as the concentration of SPDP.

The concentration of $\mathrm{IgG}$ was determined as $4.8 \mathrm{mg} \mathrm{ml}^{-1}$ by dividing the $A_{280}$ value by $1.4\left(=\mathrm{mg} \mathrm{ml}^{-1}\right.$ ). To $2.16 \mathrm{mg} \mathrm{IgG}$ in $450 \mu \mathrm{l} 0.1 \mathrm{M}$-sodium phosphate $/ 0.1 \mathrm{M}-\mathrm{NaCl}, \mathrm{pH} 7 \cdot 1,80.8 \mathrm{nmol}$ SPDP was rapidly added during stirring and allowed to react for $60 \mathrm{~min}$ at $25^{\circ} \mathrm{C}$ without stirring. The excess reagent and low molecular weight reaction compounds were removed by gel filtration on prepacked disposable columns (PD-10, Pharmacia) packed with Sephadex G-25 and equilibrated with $0 \cdot 2 \mathrm{M}$-sodium phosphate $/ 2 \mathrm{mM}-\mathrm{MgCl}_{2}, \mathrm{pH} 7 \cdot 1$. The IgG was collected in $1.5 \mathrm{ml} 0.2 \mathrm{M}$-sodium phosphate $/ 2 \mathrm{mM}-\mathrm{MgCl}_{2}, \mathrm{pH} 7 \cdot 1$. A $0.3 \mathrm{ml}$ sample was taken out for tests of the protein concentration and degree of substitution. The IgG concentration was measured at $280 \mathrm{~nm}$ and the degree of substitution, i.e. mol 2-pyridyl disulphide versus mol protein, was recorded at $343 \mathrm{~nm}$. The number of 2-pyridyl disulphide groups introduced into the $\mathrm{IgG}$ was calculated from the amount of pyridine-2-thione released during treatment of the modified IgG with dithiothreitol, which is equivalent to the concentration of 2-pyridyl disulphide residues in the IgG. In the present case it was found to be 2.5 .

$\beta$-Galactosidase (EC 3.2.1.23, Sigma) (7 mg) was dissolved in $0.5 \mathrm{ml} 0.1 \mathrm{M}$-sodium phosphate $/ 0.1 \mathrm{M}$ $\mathrm{NaCl} / 30 \mathrm{~mm}$-dithiothreitol, $\mathrm{pH} 7 \cdot 1$. After $1 \mathrm{~h}$ the dithiothreitol was removed by gel filtration on a PD-10 column packed with Sephadex G-25 and equilibrated with $0 \cdot 2 \mathrm{M}$-sodium phosphate $/ 2 \mathrm{mM}-\mathrm{MgCl}_{2}, \mathrm{pH} 7 \cdot 1$; the enzyme was collected in $1.5 \mathrm{ml}$. The enzyme concentration was calculated to be $4.2 \mathrm{mg} \mathrm{ml}^{-1}$ by dividing the $A_{280}$ value by 2.09 $\left(=\mathrm{mg} \mathrm{ml}^{-1}\right)$.

Thiolated $\mathrm{IgG}(1.26 \mathrm{mg})$ was mixed with $1.85 \mathrm{mg} \beta$-galactosidase, giving a total volume of $1.64 \mathrm{ml}$, and kept for $2 \mathrm{~h}$ at room temperature and one week at $6{ }^{\circ} \mathrm{C}$. Then $0.02 \% \mathrm{NaN}_{3}$ was added and the mixture stored at $6{ }^{\circ} \mathrm{C}$ before use without further purification.

Electrophoresis of prepared enzyme conjugates. This was done on a polyacrylamide gradient gel, PAA 4/30 (Pharmacia). The buffer used was $0.09 \mathrm{M}$-Tris $/ 0.08 \mathrm{M}$-borate $/ 3 \mathrm{~mm}-\mathrm{Na}{ }_{2}$ EDTA, pH 8.4 , and the electrophoresis was performed at $125 \mathrm{~V}$ for $16 \mathrm{~h}$ at $15^{\circ} \mathrm{C}$. After the electrophoresis was completed, the gel was covered with $\beta$ galactosidase substrate (see final ELISA test procedure). The active $\beta$-galactosidase could be seen as yellow bands and was photographed. The gel was then stained in $0.7 \%$ Amidoblack $10 \mathrm{~B} / 7 \%$ acetic acid for $30 \mathrm{~min}$ and destained in $7 \%$ acetic acid for $3 \mathrm{~h}$.

Final ELISA test procedure for detecting antigen. Polystyrene test tubes (vol. $4 \mathrm{ml}$ ) were washed once with $2 \mathrm{ml}$ buffer containing $0.9 \% \mathrm{NaCl} / 0.02 \mathrm{M}$-sodium phosphate $/ 0.25 \%$ Tween $20 / 2 \mathrm{~mm}-\mathrm{MgCl}_{2}, \mathrm{pH} 7 \cdot 1$. Test sample $(200 \mu \mathrm{l})$ was added to each test tube and $100 \mu \mathrm{l}$ enzyme conjugate was added and incubated for $4 \mathrm{~h}$, shaken at 225 r.p.m. at room temperature. To the test tube $2 \mathrm{ml}$ of the washing buffer was added, and the mixture was allowed to stand for $10 \mathrm{~min}$ and then centrifuged $(2000 \mathrm{~g})$ for $10 \mathrm{~min}$ at room temperature, after which $1.7 \mathrm{ml}$ was drawn off; this procedure was repeated three times. Then $200 \mu$ l substrate, consisting of $\sigma$-nitrophenyl- $\beta$-Dgalactopyranoside (Sigma; $3.5 \mathrm{mg} \mathrm{ml}^{-1}$ in $0.2 \mathrm{M}$-sodium phosphate $/ 2 \mathrm{mM}-\mathrm{MgCl}_{2} / 20 \%$ methanol, $\mathrm{pH} 7 \cdot 1$ ), was added and the test tubes were incubated for $1 \mathrm{~h}$. The reaction was stopped by adding $0.7 \mathrm{ml} 0.7 \mathrm{M}-\mathrm{Na}_{2} \mathrm{CO}_{3}$. The test tubes were finally centrifuged $(2000 \mathrm{~g})$ at room temperature for $10 \mathrm{~min}$ and the $A_{418}$ of the supernatants was recorded by using a Beckman spectrophotometer equipped with a micro-quartz cuvette with a $1 \mathrm{~cm}$ light path.

Optimization of some parameters of the ELISA test. The effect of different washing procedures of the antigen, using $R$. meliloti strain $29\left(10^{6}\right.$ cells $\left.\mathrm{ml}^{-1}\right)$, was studied by applying the described ELISA test, using enzyme conjugate derived from antisera prepared by whole-cell immunization, $2 \mu \mathrm{g} \mathrm{IgG} \mathrm{ml}{ }^{-1}$. The antigen used was washed three times in different buffers before use, namely : (1) distilled water, (2) $0.02 \mathrm{M}$-sodium phosphate/0.5 M$\mathrm{NaCl}$, pH 7.1, (3) $0.02 \mathrm{M}$-sodium phosphate $/ 0.02 \mathrm{M}-\mathrm{NaCl}, \mathrm{pH} 7 \cdot 1$, (4) $0.02 \mathrm{M}$-sodium phosphate $/ 0.02 \mathrm{M}$ $\mathrm{NaCl} / 0.5 \%$ Tween $20, \mathrm{pH} 7 \cdot 1$; and (5) the antigen was boiled for $30 \mathrm{~min}$ in $0.02 \mathrm{M}$-sodium phosphate/0.02 $\mathrm{M}$ $\mathrm{NaCl}, \mathrm{pH} 7 \cdot 1$, and washed in the same buffer.

The effect on the ELISA test of using antigens of different origin was studied using $R$. meliloti strain $29(1 \times$ $10^{7.6}$ cells $\mathrm{ml}^{-1}$ ) grown on either solid B III or liquid B III substrate (Bishop et al., 1976). The enzyme conjugate used in this study derived from antisera produced by whole-cell immunization, $2 \mu \mathrm{g} \mathrm{IgG} \mathrm{m}^{-1}$. The test procedure was carried out as described earlier. 
The effect on enzyme conjugate activity of dilution in different buffers was studied. A stock culture of enzyme conjugate derived from antisera prepared by whole-cell immunization was diluted, to a final concentration of $2 \mu \mathrm{g}$ IgG ml ${ }^{-1}$, in different buffers, namely: (1) $0.9 \% \mathrm{NaCl} / 0.3 \%$ dextran $/ 0.5 \%$ Tween $20 / 0.02 \mathrm{M}$-sodium phosphate, pH $7 \cdot 1$; (2) $0 \cdot 2 \mathrm{M}$-sodium phosphate $/ 2 \mathrm{mM}-\mathrm{MgCl}_{2} / 2 \mathrm{mg}$ human $\mathrm{IgG} \mathrm{ml}{ }^{-1}$ (Sigma), $\mathrm{pH} 7 \cdot 1$; (3) $0 \cdot 2 \mathrm{M}-\mathrm{NaCl} / 2 \mathrm{mM}$ $\mathrm{MgCl}_{2} / 0.1 \%$ Tween 20 , pH $7 \cdot 1$; (4) $0.9 \% \mathrm{NaCl} / 0.3 \%$ dextran $/ 0.5 \%$ Tween $20 / 0.02 \mathrm{M}$-sodium phosphate $/ 2 \mathrm{mM}$ $\mathrm{MgCl}_{2}$, pH 7.1. To $200 \mu$ l of enzyme conjugate $100 \mu$ l substrate (for concentration see description of the final test procedure) was added. After $3 \mathrm{~min}$ the enzyme reaction was stopped by adding $0.7 \mathrm{ml} 0.7 \mathrm{M}-\mathrm{Na}_{2} \mathrm{CO}_{3}$ and the $A_{418}$ was recorded.

The effect of enzyme conjugate concentration on the ELISA test was investigated by using $R$. meliloti strain 29 $\left(10^{6}\right.$ cells $\left.\mathrm{ml}^{-1}\right)$ and varying the concentration of enzyme conjugate when applying the ELISA test. The enzyme conjugate investigated was derived from antisera produced by whole-cell immunization.

The effect of the time for which the antigen was incubated with the enzyme conjugate was studied, using $R$. meliloti strain $29\left(1 \times 10^{3 \cdot 5}\right.$ cells ml $\mathrm{m}^{-1}$ and $1 \times 10^{4 \cdot 5}$ cells $\left.\mathrm{ml}^{-1}\right)$ and enzyme conjugate derived from antisera produced by whole-cell immunization, $2 \mu \mathrm{g} \mathrm{IgG} \mathrm{ml}{ }^{-1}$. The cell suspensions were incubated with the enzyme conjugate for periods up to $24 \mathrm{~h}$, after which the the ELISA test procedure was performed as before.

The linearity of the formation of the product during incubation of the enzyme conjugate with antigen was studied using $R$. meliloti strain $29\left(10^{8}\right.$ cells $\left.\mathrm{ml}^{-1}\right)$ and enzyme conjugate derived from antisera produced by whole-

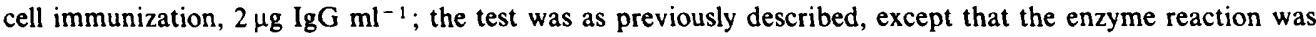
stopped at $15 \mathrm{~min}$ intervals. This experiment was also used for a study of the absorbance maximum of the product, using the sample being incubated for $60 \mathrm{~min}$ and monitoring between $350 \mathrm{~nm}$ and $550 \mathrm{~nm}$.

Identification of antigen using the ELISA test. Rhizobium meliloti strains were tested with the ELISA test at different cell concentrations and with enzyme conjugate derived from either LPS immunization or whole-cell immunization. Nodules from aseptically grown inoculated lucerne were crushed and suspended in distilled water at $10^{5}$ cells $\mathrm{ml}^{-1}$, and incubated with enzyme conjugate derived from antisera produced by whole-cell immunization, $2 \mu \mathrm{g} \mathrm{IgG} \mathrm{ml}^{-1}$.

\section{RESULTS AND DISCUSSION}

A new method for preparing enzyme conjugate used in ELISA tests is presented. This technique offers several advantages over that suggested by Clark \& Adams (1977), the main one being detection and identification of micro-organisms in samples with very low cell concentrations. For instance, in the present study, Rhizobium meliloti strains were detected and differentiated in samples containing $1 \times 10^{3}$ cells $\mathrm{ml}^{-1}$ (Table 1$)$. The technique presented will therefore facilitate further studies in this field in samples with low cell concentrations. A beneficial step in preparing the ELISA conjugates was the choice of $\beta$-galactosidase as enzyme, which enabled the free -SH groups present on the enzyme to be used in the coupling reaction between the antibody and the enzyme. $\beta$-Galactosidase is also easily available, and very stable. In the conventional method (Voller et al., 1976), conjugation is made by glutaraldehyde. The use of a hetero-bifunctional reagent such as SPDP offers several advantages: homopolymerization and intramolecular (versus intermolecular) cross-linking is avoided, the reactions can be performed under mild conditions, and the degree of substitution with protected thiol groups is controllable and can be determined. In the present study, the degree of substitution, i.e. mol disulphide versus mol IgG, was between 2.4 and 2.5 . Electrophoresis showed that most of the conjugate consisted of one molecule of $\beta$-galactosidase and one IgG, $1: 1$, and some $1: 2$ and $1: 3$. Further purification did not therefore seem necessary.

Several parameters of the ELISA test procedure were investigated in order to evaluate a proper method for routine analysis in the future. Washing of the antigen in distilled water was preferable to other pretreatments (Table 2). This is in contrast to the findings of Kishinevsky \& Bar-Joseph (1978), who presented results indicating that higher ELISA values were obtained with preheated antigens. This difference might be explained if thermostable antigens are released, as expected from the lysed cells. Nevertheless, it was decided to wash the cells in distilled water during routine ELISA tests. Slightly higher ELISA values were obtained with antigen from cells grown in liquid culture than with that from cells grown on solid substrate. However, this character was not statistically significant and of no importance for the ELISA values. When the conjugate was diluted in different buffers, differences between the buffers were small, but the buffer containing dextran, Tween $20, \mathrm{MgCl}_{2}$ and sodium phosphate in saline 
Table 1. Cross-reactivity of four strains of $R$. meliloti using the ELISA test

Enzyme conjugates were prepared from antisera of strain 29 prepared by whole-cell immunization $\left(2 \cdot 0 \mu \mathrm{g} \mathrm{IgG} \mathrm{ml}^{-1}\right)$ and by LPS immunization $\left(2 \cdot 3 \mu \mathrm{g} \mathrm{IgG} \mathrm{ml}^{-1}\right)$. Three replicates were done of each test. The control was distilled water.

\begin{tabular}{|c|c|c|c|c|c|c|c|}
\hline \multirow[b]{2}{*}{ Strain no. } & \multirow{2}{*}{$\begin{array}{l}\log (\text { No. of } \\
\left.\text { cells } \mathrm{ml}^{-1}\right)\end{array}$} & \multicolumn{3}{|c|}{ Whole-cell immunization } & \multicolumn{3}{|c|}{ LPS immunization } \\
\hline & & $A_{418}$ & SD & $P$ value* & $A_{418}$ & SD & $P$ value ${ }^{*}$ \\
\hline Control & 0 & $0 \cdot 140$ & $0 \cdot 028$ & - & $0 \cdot 114$ & 0.021 & - \\
\hline 29 & $\begin{array}{l}7.6 \\
4.4 \\
3.0 \\
2.5\end{array}$ & $\begin{array}{l}0.734 \\
0.447 \\
0.287 \\
0.215\end{array}$ & $\begin{array}{l}0.029 \\
0.012 \\
0.016 \\
0.019\end{array}$ & $\begin{array}{c}0.005 \\
0.005 \\
0.05 \\
\text { NS }\end{array}$ & $\begin{array}{l}0.394 \\
0 \cdot 167 \\
0 \cdot 114 \\
0 \cdot 117\end{array}$ & $\begin{array}{l}0.033 \\
0.032 \\
0.007 \\
0.035\end{array}$ & $\begin{array}{c}0.010 \\
\text { NS } \\
\text { NS } \\
\text { NS }\end{array}$ \\
\hline 4 & $\begin{array}{l}7 \cdot 6 \\
4 \cdot 4 \\
3 \cdot 0 \\
2 \cdot 5\end{array}$ & $\begin{array}{l}0.448 \\
0.212 \\
0.211 \\
0.121\end{array}$ & $\begin{array}{l}0.015 \\
0.017 \\
0.011 \\
0.018\end{array}$ & $\begin{array}{c}0.010 \\
0.005 \\
0.05 \\
\text { NS }\end{array}$ & $\begin{array}{l}0.395 \\
0.174 \\
0 \cdot 120 \\
0.099\end{array}$ & $\begin{array}{l}0.052 \\
0.035 \\
0.017 \\
0.023\end{array}$ & $\begin{array}{l}\text { NS } \\
\text { NS } \\
\text { NS } \\
\text { NS }\end{array}$ \\
\hline 23 & $\begin{array}{l}7 \cdot 6 \\
4 \cdot 4 \\
3 \cdot 0 \\
2 \cdot 5\end{array}$ & $\begin{array}{l}0.553 \\
0 \cdot 264 \\
0 \cdot 160 \\
0 \cdot 130\end{array}$ & $\begin{array}{l}0.020 \\
0.027 \\
0.005 \\
0.016\end{array}$ & $\begin{array}{r}0.05 \\
0.05 \\
0.05 \\
\text { NS }\end{array}$ & $\begin{array}{l}0.481 \\
0 \cdot 188 \\
0.090 \\
0 \cdot 110\end{array}$ & $\begin{array}{l}0.024 \\
0.036 \\
0.005 \\
0.009\end{array}$ & $\begin{array}{l}\text { NS } \\
\text { NS } \\
\text { NS } \\
\text { NS }\end{array}$ \\
\hline 27 & $\begin{array}{l}7 \cdot 6 \\
4 \cdot 4 \\
3 \cdot 0 \\
2 \cdot 5\end{array}$ & $\begin{array}{l}0.446 \\
0.217 \\
0.158 \\
0.131\end{array}$ & $\begin{array}{l}0.065 \\
0.049 \\
0.009 \\
0.019\end{array}$ & $\begin{array}{r}0.05 \\
0.05 \\
0.05 \\
\text { NS }\end{array}$ & $\begin{array}{l}0.255 \\
0.187 \\
0.107 \\
0.093\end{array}$ & $\begin{array}{l}0.006 \\
0.025 \\
0.004 \\
0.018\end{array}$ & $\begin{array}{l}\text { NS } \\
\text { NS } \\
\text { NS } \\
\text { NS }\end{array}$ \\
\hline
\end{tabular}

* Each strain was compared to strain 29 at the same cell concentration; strain 29 was compared to the control at each cell concentration. NS, Not significant.

Table 2. Effect on the ELISA test of different washing procedures for antigen of R. meliloti strain 29

The enzyme conjugate was derived from antiserum prepared by whole-cell immunization, $2 \mu \mathrm{g}$ IgG $\mathrm{ml}^{-1}$. Three replicates were done of each test.

Preparation of antigen by washing in:

Distilled water

$0.02 \mathrm{M}$-Sodium phosphate $/ 0.5 \mathrm{~m}-\mathrm{NaCl}, \mathrm{pH} 7 \cdot 1$

$0.02 \mathrm{~m}$-Sodium phosphate $/ 0.02 \mathrm{M}-\mathrm{NaCl}, \mathrm{pH} 7 \cdot 1$

$0.02 \mathrm{M}$-Sodium phosphate $/ 0.02 \mathrm{M}-\mathrm{NaCl} /$

$0.5 \%$ Tween $20, \mathrm{pH} 7 \cdot 1$

'Boiled antigen' in $0.02 \mathrm{M}$-sodium phosphate/ $0.02 \mathrm{M}-\mathrm{NaCl}, \mathrm{pH} 7 \cdot 1$

\begin{tabular}{|c|c|c|c|}
\hline $\begin{array}{l}\log (\text { No. of } \\
\left.\text { cells } \mathrm{ml}^{-1}\right)\end{array}$ & $A_{418}$ & SD & $P$ value $*$ \\
\hline $4 \cdot 5$ & $0 \cdot 547$ & 0.047 & - \\
\hline 0 & $0 \cdot 121$ & 0.010 & - \\
\hline $\begin{array}{l}4 \cdot 5 \\
0\end{array}$ & $\begin{array}{l}0.292 \\
0 \cdot 127\end{array}$ & $\begin{array}{l}0.022 \\
0.017\end{array}$ & $\begin{array}{c}0.05 \\
\text { NS }\end{array}$ \\
\hline $\begin{array}{l}4 \cdot 5 \\
0\end{array}$ & $\begin{array}{l}0.417 \\
0.139\end{array}$ & $\begin{array}{l}0.031 \\
0.027\end{array}$ & $\begin{array}{c}0 \cdot 10 \\
\text { NS }\end{array}$ \\
\hline $\begin{array}{l}4 \cdot 5 \\
0\end{array}$ & $\begin{array}{l}0.463 \\
0 \cdot 118\end{array}$ & $\begin{array}{l}0.044 \\
0.039\end{array}$ & $\begin{array}{l}\text { NS } \\
\text { NS }\end{array}$ \\
\hline $\begin{array}{l}4 \cdot 5 \\
0\end{array}$ & $\begin{array}{l}0.333 \\
0 \cdot 133\end{array}$ & $\begin{array}{l}0.001 \\
0.017\end{array}$ & $\begin{array}{c}0.05 \\
\text { NS }\end{array}$ \\
\hline
\end{tabular}

* Each washing in buffer was compared to washing in distilled water at each cell concentration. NS, Not significant.

gave the best enzyme activity. For routine ELISA, it was decided to use this buffer composition. The relation between the concentration of the enzyme conjugate and the ELISA test (Fig. 1) demonstrated that the optimal reaction between enzyme conjugate and antigen occurred at an enzyme conjugate concentration of $2 \mu \mathrm{g} \mathrm{IgG} \mathrm{ml} \mathrm{Ig}^{-1}$ with respect to background levels. Consequently, this will be the concentration to be used in routine ELISA. The optimum time for incubation of the antigen with the enzyme conjugate was $4 \mathrm{~h}$ (Fig. 2). The enzyme reaction was linear for at least $75 \mathrm{~min}$; it was decided to incubate the ELISA samples for $1 \mathrm{~h}$. The maximum absorbance of the product was at $418 \mathrm{~nm}$, and the ELISA test samples will be measured at this 


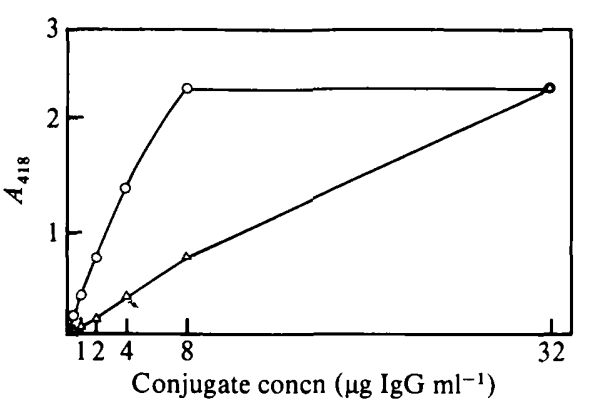

Fig. 1

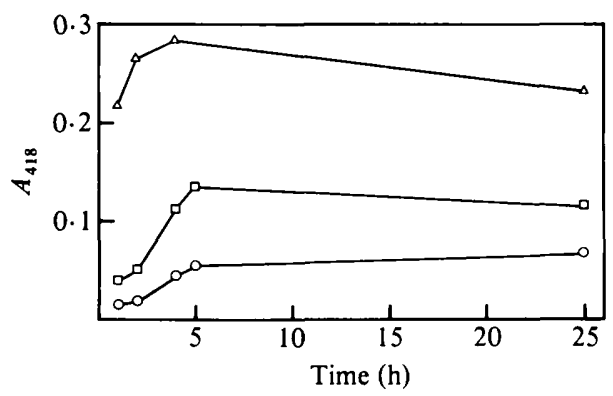

Fig. 2

Fig. 1. Effect of enzyme conjugate concentration on the ELISA test. The enzyme conjugate was prepared from antisera produced by whole-cell immunization. Three replicates were done of each test. $O$, Concentration of $R$. meliloti strain 29 at $1 \times 10^{5}$ cells $\mathrm{ml}^{-1} ; \Delta$, no bacteria (control).

Fig. 2. Effect on the ELISA test of the time of incubation of $R$. meliloti strain 29 with conjugate prepared from antisera produced by whole-cell immunization, $2 \cdot 0 \mu \mathrm{g} \mathrm{IgG} \mathrm{ml}{ }^{-1}$. Three replicates were done of each test. Cell concentrations $\left[\log \left(\right.\right.$ no. of cells $\left.\left.\mathrm{ml}^{-1}\right)\right]: \Delta, 4 \cdot 5 ; \square, 3.5 ; \bigcirc, 0$ (control, distilled water).

\section{Table 3. Cross-reactivity of nodule extracts of four strains of $R$. meliloti using the ELISA test}

The cell concentration of each strain was $1 \times 10^{5} \mathrm{cells} \mathrm{ml}^{-1}$; the enzyme conjugate used was derived from antisera produced by whole-cell immunization of $R$. meliloti strain $29,2 \mu \mathrm{g} \mathrm{IgG} \mathrm{ml}^{-1}$. Three replicates were done of each test. The control was distilled water.

$\begin{array}{cccc}\text { Strain no. } & A_{418} & \text { SD } & P \text { value* } \\ \text { Control } & 0.162 & 0.030 & 0.010 \\ 29 & 0.640 & 0.021 & - \\ 4 & 0.284 & 0.035 & 0.010 \\ 23 & 0.523 & 0.027 & 0.10 \\ 27 & 0.481 & 0.040 & 0.05 \\ & \text { * Samples compared to strain 29. }\end{array}$

wavelength. The results of the testing of different ELISA procedures showed that the presented final ELISA test procedure gave maximum ELISA values. When applying the designed ELISA test with enzyme conjugate derived by whole-cell immunization it was possible to detect and recognize strains of rhizobia in samples containing $1 \times 10^{3}$ cells ml $^{-1}$ (Table 1), a concentration lower than in earlier reports (Kishinevsky \& Bar-Joseph, 1978; Berger et al., 1979; Morley \& Jones, 1980). Strain specificity of the ELISA test was also obtained in nodule extracts containing $1 \times 10^{5}$ cells ml $\mathrm{ml}^{-1}$ (Table 3 ).

The enzyme conjugate derived from the antisera produced by LPS immunization was compared to the 'whole-cell immunization' enzyme conjugate and it was concluded that the 'whole-cell' enzyme conjugate was preferable (Table 1). Despite the LPS antibodies not being completely unspecific, future applications will concentrate on the purification of the antibodies obtained by whole-cell immunization.

We wish to thank Dr G. Björnhag and G. Alfven for kind assistance with rabbit immunization. This work was supported by a grant from the Swedish Agricultural Research Council.

\section{REFERENCES}

Berger, J. A., May, S. N., Berger, L. R. \& Bohlool, B. B. (1979). Colorimetric enzyme-linked immunosorbent assay for the identification of strains of Rhizobium in culture and in the nodules of lentils. Applied and Environmental Microbiology 37, 642-646.
Bishop, P. E., Guevara, J. G., Engelke, J. A. \& Evans, H. J. (1976). Relation between glutamine synthetase and nitrogenase activities in the symbiotic association between Rhizobium japonicum and Glycine max. Plant Physiology 57, 542-546. 
Carlsson, J., Drevin, H. \& Axén, R. (1978). Protein thiolation and reversible protein-protein conjugation. $N$-Succinimidyl-3-(2-pyridyldithio)propionate, a new heterobifunctional reagent. Biochemical Journal 173, 723-737.

Clark, M. F. \& Adams, A. N. (1977). Characteristics of the microplate methods of enzyme-linked immunosorbent assay for the detection of plant viruses. Journal of General Virology 34, 475-483.

Engvall, E. \& Perlmann, P. (1971). Enzyme-linked immunosorbent assay (ELISA). Quantitative assay of IgG. Immunochemistry 8, 871-874.

Engvall, E. \& Perlmann, P. (1972). Quantitation of specific antibodies by enzyme-linked anti-immunoglobulin in antigen-coated tubes. Journal of Immunology 109, 129-135.

Johnston, A. W. B. \& Beringer, J. E. (1975). Identification of the Rhizobium strains in pea root nodules using genetic markers. Journal of General Microbiology 87, 343-350.

KISHINEVSKY, B. \& BAR-JosePH, M. (1978). Rhizobium strain identification in Arachis hypogaea nodules by enzyme-linked immunosorbent assay (ELISA). Canadian Journal of Microbiology 24, 1537-1543.

Morley, S. J. \& Jones, G. D. (1980). A note on the highly sensitive modified ELISA technique for Rhizobium strain identification. Journal of Applied Bacteriology 49, 103-109.

Nakane, P. K. \& Pierce, G. B. (1966). Enzymelabelled antibodies: preparation and application for the localisation of antigens. Journal of Histochemistry and Cytochemistry 14, 929-931.
Schwinghamer, E. A. \& Dudman, W. F. (1971). Evaluation of spectinomycin resistance as a marker for ecological studies with Rhizobium spp. Journal of Applied Bacteriology 36, 262-271.

Stuchbury, T., Shipton, M., Norris, R., Malthouse, J. P. G., Brocklehurst, K., Herbert, J. A. L. \& SuschitzKY, H. (1975). A reporter group delivery system with both absolute and selective specificity for thiolgroups and an improved fluorescent probe containing the 7-nitrobenzo-2-oxa-1,3diazole moiety. Biochemical Journal 151, 417-432.

VinCENT, J. M. (1970). A Manual for the Practical Study of the Root Nodule Bacteria. IBP Handbook no. 15. Oxford: Blackwell.

Voller, A., Bartlett, D. E., Clark, M. F. \& Adams, A. N. (1976). The detection of viruses by enzymelinked immunosorbent assay (ELISA). Journal of General Virology 33, 165-167.

Weissbach, A. \& Hurwitz, J. (1958). The formation of 2-keto-3-deoxyheptonic acid in extracts of Escherichia coli B. Journal of Biological Chemistry 234, 705709.

Westphal, A. \& Jann, K. (1965). Bacterial lipopolysaccharides. Extraction with phenol-water and further applications of the procedure. Methods in Carbohydrate Chemistry 5, 83-91.

WiCker, R. \& AVRameas, S. (1969). Localization of virus antigens by enzyme-labelled antibodies. Journal of General Virology 4, 465-471. 